\author{
농산부산물 발효사료 급여가 비육흑염소의 생산성 및 \\ 영양소 이용율에 미치는 영향
}

최순호 ${ }^{1} \cdot$ 황보순 $^{2 *} \cdot$ 김상우 $^{1} \cdot$ 조영무 $^{1} \cdot$ 유용희 $^{1} \cdot$ 김태일 $^{1} \cdot$ 김맹중 $^{1} \cdot$ 이상민 $^{1} \cdot$ 최창원 $^{2} \cdot$

서병부 $^{2} \cdot$ 조익환 $^{2} \cdot$ 홍성구 $^{1}$

\title{
Effects of Fermented feed with Agricultural by-products on the Growth Performance and Nutrients Utilization in Fattening Korean Black Goats
}

\author{
Sun $\mathrm{Ho} \mathrm{Choi}^{1}$, Soon Hwangbo ${ }^{2 *}$, Sang Woo Kim¹, Young Moo Cho', Yeoung Hee Yoo', \\ Tae II Kim ${ }^{1}$, Maeong Joung $\mathrm{Kim}^{1}$, Sang Min Lee ${ }^{1}$, Chang Weon Choi ${ }^{2}$, Byeong Bu Seo ${ }^{2}$, \\ Ik Hwan $\mathrm{Jo}^{2}$ and Seonng Gu Hong ${ }^{1}$
}

\begin{abstract}
This study was conducted to investigate the feeding fermented agro-industrial by-products on estimating the productivity and nutrient utilization of fattening black goats. Four experimental groups were set up with each of 6 animals for a 30 days feeding trial on growth performance and 12 black goats on nutrient digestibility were allocated to 4 groups of 3 animals each by latin-square design, control (offered concentrate and rice straw) and 3 treatment groups (offered fermentation feed and rice straw). Average daily gain (ADG) showed a significant high in control group, T3 was lower than other groups $(\mathrm{p}<0.05)$. $\mathrm{DM}$ and $\mathrm{OM}$ intake (kg/head) were $718.8,680.9 \mathrm{~g}$ and $634.2 \sim 699.2 \mathrm{~g}, 602.8 \sim 660.4 \mathrm{~g}$ for control and treatment groups, respectively. As increasing of rice bran content was decreased feed intake. Digestibility of $\mathrm{DM}$ and $\mathrm{OM}$ for control group were significantly higher than treatment groups $(\mathrm{p}<0.05)$, and $\mathrm{T} 3$ treatment group with $30 \%$ rice bran was the lowest among treatment groups. Nitrogen retention was significantly higher in control and $\mathrm{T} 1$ groups. Thus, these results showed that productivity and nutrient utilization were similar between fermentation feeds with agricultural by-products and commercial feeds. However, this study was suggested that it must contain less than $5.0 \%$ crude fat because of feed efficient was decreased by increasing of rice bran content.
\end{abstract}

(Key words : Wet brewer's grain, Performance, Rice bran, Nutrient digestibility, Korean black goat)

$$
\begin{array}{ll}
\text { I . 서 론 이오 연료생산이 늘어나면서 사료원료 수급상 } \\
\text { 황이 더욱 악화되고 있으며 국제 곡물가격의 }
\end{array}
$$

근래 국가마다 곡물이나 종실류를 이용한 바 지속적인 상승으로 국내 배합사료 가격도 큰

\footnotetext{
${ }^{1}$ 농촌진흥청 국립축산과학원 (National Institute of Animal Science, RDA.)

${ }^{2}$ 대구대학교 (Daegu University, Gyeongsan, 712-714, Korea)

Corresponding author: Soon Hwangbo, Daegu University, Gyeongsan, 712-714, Korea.
}

Tel: 053-850-6720, Fax: 053-850-6729, E-mail: simona@daegu.ac.kr 
폭으로 상승하고 있다. 국내 축산업은 사료생 산기반이 취약하여 배합사료 원료뿐만 아니라 조사료도 수입하여 가축을 사육하고 있어 축산 물 생산비가 높아 무한 경쟁시대의 국내 축산 업의 경쟁력 제고에 큰 장애요인이 되고 있다.

이러한 어려움을 해결하기 위해 가축사육 농 가에서는 사료비 절감방안으로 농업부산물을 사료화하여 가축에 급여하는 추세가 증가하고 있으며, 연구분야에서도 농업부산물의 사료가 치 및 이용성에 대한 연구(Lee et al., 2003; Kim et al., 2007; Lee, 2008)가 지속적으로 수 행되고 있다.

국내 농산부산물 중에 버섯부산물, 맥주박, 비지, 미강 등이 사료원료로 많이 이용되고 있 으며. 특히 맥주박은 에너지가 높고 단백질과 섬유소 함량이 높아 사료적인 가치가 높은 것 으로 보고되었으며 (Gondwe et al., 1999), 맥주 박의 단백질은 반추위 우회 단백질 비율이 높 아 (Polan et al., 1985) 맥주박을 젖소에 급여할 경우 산유량과 유지방 등이 증가한다고 보고하 였다 (Belibasakis and Tsigogianni, 1996).

또한, 국내 버섯부산물 생산량은 약 167 만 톤 (Kim et al., 2007)정도이며, 영양성분 함량은 $\mathrm{NDF} 65 \sim 79 \%$, CP $8 \sim 12 \%$, 조회분 6 12\% 정도 로 사료자원으로 가치가 있으나, 수분함량이 $60 \%$ 이상으로 보관 중 곰팡이와 세균에 의한 변질 부패가 쉽게 될 수 있어 사료 제조과정에 서 발효화 처리가 필요하며, 적정 저장기간 설 정이 중요하다고 보고되고 있다(West et al., 1994). 이러한 농산부산물을 효율적으로 가축에 이용한다면 사료비 절감은 물론 수입 곡물사료 절감과 가축생산성을 증대시킬 수 있을 것이다.

따라서 본시험은 농산부산물을 발효사료로 제조하여 흑염소에 급여하였을 때 생산성 및 영양소 이용율을 조사하여 에너지원으로 수입 옥수수 대신 미강의 대체 효과와 맥주박, 비지, 버섯부산물 등과 같은 농산부산물의 급여효과 를 알아보고자 수행하였다.

\section{ㅍ. 재료 및 방법}

\section{1. 공시축 및 사양관리}

본 시험은 전북 남원에 위치한 국립축산과학 원 가축유전자원시험장에서 실시하였다. 사양 시험의 공시가축은 체중이 $25.8 \pm 1.72 \mathrm{~kg}$ 인 거세 흑염소 24 두, 소화율 시험은 평균체중이 $28.4 \pm$ $1.33 \mathrm{~kg}$ 인 거세흑염소 12 두를 공시하여 개체별 대사 케이지에 수용하여 실시하였으며, 시험 및 대조구의 시판사료는 1일 2회 $(09: 00,16: 00)$ 로 나누어 체중의 $2.0 \%$ (건물기준)로 제한 급여 하였고, 볏짚은 자유채식토록 하였으며 물은 자유 급수하여 충분히 음수토록 하였다.

\section{2. 시험설계 및 시험사료 제조}

본 시험의 처리는 농산부산물인 맥주박, 비 지, 버섯부산물, 미강 등을 주원료로 하여 배합 비를 각각 달리 제조한 3 처리와 시판사료 급여 구인 대조구 나누어 4 처리로 하였으며, 시험사 료 제조는 처리구별 시험사료 배합비율에 따라 각각 혼합한 후 소형발효기 (대동테크, DDK$802 \mathrm{M}$ )를 이용하여 균일하게 배합한 후 $80 \mathrm{~kg}$ 용 플라스틱 용기에 7일간 실온에서 밀봉저장 후 시험사료로 이용하였다 (RDA, 2007). 본 시험에 사용된 농산부산물사료 배합비율은 Table 1 과 같으며 시험사료의 일반조성분은 Table 2 와 같 다.

증체조사를 위한 사양시험은 처리구당 6 두씩 30 일 수행하였고, 소화율 시험은 한 처리구당 triplicated $4 \times 4$ 라틴방각법으로 실시하여 각 period는 총 30 일이 소요되었고, 사료적응기간 을 포함해 20 일 동안의 예비시험기간을 거친 후, 10 일간의 본 시험기간 동안 사료섭취량 및 분 · 뇨 배설량을 매일 측정하였다. 
Table 1. Experimental concentrates formula of feeds (\% DM)

\begin{tabular}{lrrr}
\hline & $\mathrm{T} 1$ & $\mathrm{~T} 2$ & $\mathrm{~T} 3$ \\
\hline \hline Ingredients (\%) & & & \\
Corn & 34.6 & 27.0 & 21.0 \\
Brewers grains, Wet & 15.0 & 15.0 & 15.0 \\
Soybean curd residue & 10.0 & 9.3 & 7.2 \\
Spent mushroom substrates & 15.0 & 15.0 & 15.0 \\
Rice bran & 10.0 & 20.0 & 30.0 \\
Soybean & 8.4 & 6.7 & 4.8 \\
Sesame meal & 5.0 & 5.0 & 5.0 \\
Molasses & 2.0 & 2.0 & 2.0 \\
\hline Total & 100 & 100 & 100 \\
\hline
\end{tabular}

3. 조사항목

1) 사료 섭취량 및 체중

사료 섭취량은 급여한 사료와 섭취하고 남은 사료의 차이로 구하였으며, 증체 조사를 위한 체중측정은 사양시험 개시 및 종료 시 각각 아 침사료 급여 전에 측정하였다.

2) 시료의 화학적 분석 및 소화율 측정

시료의 일반성분과 뇨 중 질소는 A.O.A.C (1995)법에 의해 분석하였고 $\mathrm{ADF}$ 와 $\mathrm{NDF}$ 함량
은 Van Soest 등 (1991)의 방법에 의해 분석하 였다. 소화율은 섭취한 사료의 양과 배설한 분 의 양을 채취하여 측정하였으며, 영양소 소화 율은 [(사료 중 포함된 영양소 함량 - 분 중 포함된 영양소 함량)/사료 중 포함된 영양소 함 량] $\times 100$ 으로 계산하였다.

3) 분과 뇨 채취

소화율 시험에서 분은 본 실험 10 일 동안 매 일 총 배설량을 칭량하고 수거한 분을 잘 혼합 한 후 이 중 $10 \%$ 를 채취하여 $60^{\circ} \mathrm{C}$ dry oven에 서 48 시간 건조한 후 중량을 측정, 건조중량으 로 환산하였으며 이들 일부는 Wiley mill의 40 mesh에서 분쇄하여 분석시료로 사용하였고, 뇨 는 질소 $(\mathrm{N})$ 손실 방지를 위해 용기에 $5 \mathrm{~N} \mathrm{HCl}$ 을 투입하여 1 일 배설량을 매일 측정하고 이 중 $10 \%$ 를 채취하여, 뇨 중 질소분석시까지 -20 ${ }^{\circ} \mathrm{C}$ 냉동고에 보관하였다.

\section{4. 통계분석}

본 실험의 결과는 SAS package program (version 8.1, USA, 2000)을 이용하여 유의성을 검정하였고, 처리군의 평균간 비교는 Duncan's multiple range test (5\% 유의수준)로 하였다 (Steel 과 Torrie, 1980).

Table 2. Chemical composition of experimental diets (\% DM)

\begin{tabular}{lccccc}
\hline Items & Control & $\mathrm{T} 1$ & $\mathrm{~T} 2$ & $\mathrm{~T} 3$ & Rice straw \\
\hline \hline Dry matter & 92.0 & 65.0 & 64.8 & 63.8 & 87.0 \\
Crude protein & 18.08 & 18.71 & 18.47 & 18.14 & 3.45 \\
$\mathrm{ADF}^{1)}$ & 28.36 & 25.36 & 26.27 & 26.50 & 37.53 \\
$\mathrm{NDF}^{2)}$ & 31.27 & 31.72 & 32.07 & 32.49 & 58.37 \\
Ether extracts & 3.39 & 3.16 & 4.94 & 6.92 & 1.27 \\
Crude ash & 4.04 & 4.57 & 4.69 & 4.09 & 9.58 \\
$\mathrm{NFC}^{3)}$ & 43.22 & 41.84 & 39.83 & 38.36 & 27.33 \\
\hline
\end{tabular}

1) $\mathrm{ADF}=$ Acid detergent fiber, ${ }^{2)} \mathrm{NDF}=$ Neutral detergent fiber,

${ }^{3)} \mathrm{NFC}=$ Non-fibrous carbohydrate (100-crude protein-NDF-ether extracts-crude ash). 
III. 결과 및 고찰

\section{1. 증체량}

농산부산물 첨가 발효사료를 흑염소에게 급 여한 결과 증체와 사료효율에 미치는 영향은 Table 3 과 같다. 시험 개시 시 체중은 25.35 $26.45 \mathrm{~kg}$ 이었고, 종료 시 체중은 대조구가 28.31 $\mathrm{kg}$ 으로 나타나 농산부산물 첨가구의 26.71 $27.51 \mathrm{~kg}$ 보다는 높은 경향이었다. 일당증체량 은 대조구가 $62.22 \mathrm{~g}$ 으로 가장 높았고, $\mathrm{T} 1$ 과 $\mathrm{T} 2$ 구가 각각 56.11 과 $53.61 \mathrm{~g}$ 이었고, $\mathrm{T} 3$ 구가 $45.27 \mathrm{~g}$ 으로 가장 낮았다 $(\mathrm{p}<0.05)$.

본 시험에서 농산부산물 시험구의 일당증체 량은 45.27 56.11 g으로 나타나, 맥주박을 20 $40 \%$ 첨가한 $\mathrm{TMR}$ 사료를 거세흑염소에게 급여 시 일당증체량이 25.2 25.7 g (Choi et al., 2006b) 보다는 높은 증체를 보였다. 이는 맥주박에 silica와 같은 분해가 잘되지 않는 물질이 다량 함유되어 있기 때문에 (Macleod, 1979) 이용효 율이 낮은 맥주박의 급여 비율이 본 시험에서 $15 \%$ 로 낮았기 때문으로 사료되며, 이러한 결과 는 맥주박 첨가를 $35 \%$ 수준으로 면양에게 급 여하였을 때 알팔파 $(17.3 \%)$, 땅콩박 $(16.8 \%)$ 및 대두박 $(6.6 \%)$ 을 급여한 대조구 보다 사료효율 과 증체가 유의하게 낮았다 (McCarthy et al.,
1990)는 보고와 일치하였다. 또한, Jo 등 (1999) 은 미강 첨가비율이 $30 \%$ 인 농산부산물을 흑염 소에게 급여 시 일당증체량이 최대 $30.8 \mathrm{~g}$ 이었 다는 결과보다는 높게 나타났다. 이와 같이 농 산부산물 급여시험의 다양한 연구 결과는 첨가 비율, 다른 단미사료와의 배합비 및 시험사료 의 일반조성분 등의 요인들이 영향을 끼친 것 으로 사료된다.

한편, 본시험에서 농산부산물을 50 59.3\% 첨 가 (맥주박 $15 \%$, 버섯부산물 $15 \%$, 비지 9.3 $10 \%$, 미강을 10 20\%)한 $\mathrm{T} 1$ 과 2 구의 일당증체 량은 시판사료를 급여한 대조구 대비 86.2 $90.2 \%$ 수준으로 $\mathrm{T} 3$ 구의 $72.8 \%$ 수준보다는 높 게 나타나, 농산부산물의 적절한 이용은 농산 부산물의 이용효율 증대 효과가 있음을 시사하 였다.

\section{2. 영양소 및 가소화 영양소 섭취량}

농산부산물 첨가 발효사료를 흑염소에게 급 여하였을 때 영양소 섭취량과 가소화영양소 섭 취량에 미치는 영향은 Table 4와 같다.

1 일 두당 건물섭취량과 유기물섭취량은 시판 사료를 급여한 대조구가 각각 718.8 과 $680.9 \mathrm{~g}$, 농산부산물 첨가구가 각각 634.2 699.2와 602.8 $\sim 60.4 \mathrm{~g}$ 으로 나타나 농산부산물 중 미강 첨가

Table 3. The effects of feeding experimental diets on body weight gain of Korean black goats

\begin{tabular}{lccccc}
\hline \multirow{2}{*}{ Items } & \multicolumn{4}{c}{ Treatments $^{1)}$} & \multirow{2}{*}{ SEM $^{2)}$} \\
\cline { 2 - 5 } & Control & $\mathrm{T} 1$ & $\mathrm{~T} 2$ & $\mathrm{~T} 3$ & \\
\hline \hline Initial body wt., $\mathrm{kg}$ & 26.45 & 25.83 & 25.67 & 25.35 & 1.87 \\
Finial body wt., $\mathrm{kg}$ & 28.31 & 27.51 & 27.28 & 26.71 & 1.92 \\
Total body gain, $\mathrm{kg}$ & $1.86^{\mathrm{a}}$ & $1.68^{\mathrm{b}}$ & $1.60^{\mathrm{b}}$ & $1.35^{\mathrm{c}}$ & 0.15 \\
Average daily gain (g/day) & $62.22^{\mathrm{a}}$ & $56.11^{\mathrm{b}}$ & $53.61^{\mathrm{b}}$ & $45.27^{\mathrm{c}}$ & 5.03 \\
\hline
\end{tabular}

${ }^{1)}$ See Table $1,{ }^{2)}$ Standard error of the mean.

${ }^{a, b, c}$ Means in a row with different superscripts are significantly different $(p<0.05)$. 
Table 4. The effects of feeding experimental diets on nutrient intake and digestible nutrient intake in Korean black goats

\begin{tabular}{|c|c|c|c|c|c|}
\hline \multirow{2}{*}{ Items } & \multicolumn{4}{|c|}{ Treatments $^{1)}$} & \multirow{2}{*}{$\mathrm{SEM}^{2}$} \\
\hline & Control & $\mathrm{T} 1$ & $\mathrm{~T} 2$ & $\mathrm{~T} 3$ & \\
\hline \multicolumn{6}{|l|}{ Intake (g/d) } \\
\hline Dry matter & 718.8 & 699.2 & 663.0 & 634.2 & 50.8 \\
\hline Organic matter & 680.9 & 660.4 & 627.0 & 602.8 & 48.1 \\
\hline Crude protein & 106.4 & 109.7 & 107.2 & 100.5 & 8.62 \\
\hline $\mathrm{ADF}^{3)}$ & $218.6^{\mathrm{a}}$ & $194.1^{\mathrm{ab}}$ & $185.6^{\mathrm{b}}$ & $178.9^{\mathrm{b}}$ & 14.0 \\
\hline $\mathrm{NDF}^{4)}$ & $268.2^{\mathrm{a}}$ & $258.6^{\mathrm{ab}}$ & $239.4^{\mathrm{ab}}$ & $231.5^{\mathrm{b}}$ & 17.9 \\
\hline Ether extracts & $21.0^{\mathrm{c}}$ & $19.5^{\mathrm{c}}$ & $30.1^{\mathrm{b}}$ & $44.26^{\mathrm{a}}$ & 2.39 \\
\hline $\mathrm{NFC}^{5)}$ & $285.2^{\mathrm{a}}$ & $272.5^{\mathrm{a}}$ & $250.2^{\mathrm{ab}}$ & $226.4^{\mathrm{b}}$ & 19.5 \\
\hline \multicolumn{6}{|l|}{ Digestible nutrient Intake (g/d) } \\
\hline Dry matter & $486.0^{\mathrm{a}}$ & $433.5^{\mathrm{a}}$ & $417.6^{\mathrm{a}}$ & $342.2^{\mathrm{b}}$ & 35.7 \\
\hline Organic matter & $502.8^{\mathrm{a}}$ & $455.9^{\mathrm{a}}$ & $435.3^{\mathrm{ab}}$ & $371.3^{\mathrm{b}}$ & 34.6 \\
\hline Crude protein & 75.0 & 76.1 & 73.1 & 61.8 & 9.05 \\
\hline $\mathrm{ADF}$ & $100.6^{\mathrm{a}}$ & $83.4^{\mathrm{ab}}$ & $72.2^{\mathrm{bc}}$ & $56.8^{\mathrm{c}}$ & 10.5 \\
\hline $\mathrm{NDF}$ & $180.9^{\mathrm{a}}$ & $144.4^{\mathrm{b}}$ & $131.8^{\mathrm{b}}$ & $93.6^{\mathrm{c}}$ & 13.7 \\
\hline Ether extracts & $16.3^{\mathrm{c}}$ & $13.4^{\mathrm{c}}$ & $21.0^{\mathrm{b}}$ & $29.9^{\mathrm{a}}$ & 1.91 \\
\hline NFC & $230.5^{\mathrm{a}}$ & $221.9^{\mathrm{a}}$ & $209.3^{\mathrm{ab}}$ & $186.0^{\mathrm{b}}$ & 14.3 \\
\hline DM Intake, $\mathrm{g} / \mathrm{kg}$ of $\mathrm{BW}^{0.75}$ & $57.3^{\mathrm{a}}$ & $56.0^{\mathrm{a}}$ & $52.7^{\mathrm{b}}$ & $51.6^{\mathrm{b}}$ & 1.16 \\
\hline DM Intake/BW (\%) & 2.47 & 2.41 & 2.32 & 2.29 & 0.09 \\
\hline
\end{tabular}

${ }^{1)}$ See Table 1, ${ }^{2)}$ Standard error of the mean, ${ }^{3)} \mathrm{ADF}=$ Acid detergent fiber,

${ }^{4)} \mathrm{NDF}=$ Neutral detergent fiber, ${ }^{5)} \mathrm{NFC}=$ Non-fibrous carbohydrate.

$\mathrm{a}, \mathrm{b}, \mathrm{c}$ Means in a row with different superscripts are significantly different $(\mathrm{p}<0.05)$.

구가 높을수록 섭취량이 낮아지는 경향으로 나 타났다. 조단백질 섭취량은 $100.5 \sim 109.7 \mathrm{~g}$ 의 범 위로 나타나 시험구간 차이가 없었다. $\mathrm{ADF}$, $\mathrm{NDF}$ 및 NFC 섭취량은 대조구가 각각 218.6, 268.2 와 $285.2 \mathrm{~g}$ 으로 가장 높았으며 $(\mathrm{p}<0.05)$, 미 강을 $30 \%$ 첨가한 $\mathrm{T} 3$ 구가 $178.9,231.5$ 과 226.4 $\mathrm{g}$ 으로 가장 낮았다 $(\mathrm{p}<0.05)$. 그러나 조지방 섭 취량은 $\mathrm{T} 3$ 구가 $44.26 \mathrm{~g}$ 으로 가장 높았고, 대조 구와 $\mathrm{T} 1$ 구가 각각 21 과 $19.5 \mathrm{~g}$ 으로 가장 낮았 다 $(\mathrm{p}<0.05)$.
1 일 가소화 건물과 유기물 섭취량은 $\mathrm{T} 3$ 구에 비하여 대조구와 $\mathrm{T} 1$ 구가 유의하게 높았으며 $(\mathrm{p}<0.05)$, 가소화 조단백질 섭취량은 시험구간 차이가 없었다. 가소화 $\mathrm{ADF}, \mathrm{NDF}$ 및 $\mathrm{NFC}$ 섭 취량은 대조구와 $\mathrm{T} 1$ 구가 $\mathrm{T} 3$ 구 보다 유의하게 높았으며 $(\mathrm{p}<0.05)$, 가소화 조지방 섭취량은 이 와는 반대로 $\mathrm{T} 3$ 구가 가장 높았다 $(\mathrm{p}<0.05)$. 한 편, 대사체중 당 건물섭취량은 대조구와 $\mathrm{T} 1$ 구 가 각각 57.3 과 $56 \mathrm{~g}$ 으로 $\mathrm{T} 2$ 와 $\mathrm{T} 3$ 구의 각각 52.7 과 $51.6 \mathrm{~g}$ 보다는 유의하게 높았다 $(\mathrm{p}<0.05)$. 
체중에 대한 건물섭취비율은 $2.29 \sim 2.47 \%$ 의 범 위로 시험구간 차이가 없었으나 대사체중 당 건물섭취량과 유사한 경향이었다.

$\mathrm{NRC} \mathrm{(1981)에서는} \mathrm{체중} 30 \mathrm{~kg}$ 인 흑염소의 유 지 (중활동)를 위한 1 일 가소화 조단백질은 52 $\mathrm{g}$ 이며, 일당 증체량 $50 \mathrm{~g}$ 을 충족시키기 위한 가 소화 조단백질은 $10 \mathrm{~g}$ 이 추가로 요구된다고 제 시하고 있다. 본 시험에서 가소화 조단백질 섭 취량은 $61.8 \sim 76.1 \mathrm{~g}$ 범위이며, 사양시험을 통한 일당 증체량은 45.27 62.22 g (Table 3)으로 나 타나 NRC 제시와 일치하는 결과로 나타났다.

한편, 맥주박은 반추위내 분해되지 않는 우 회 단백질 비율이 높아 (Polan et al., 1985) 비 육우(Hathch et al., 1972) 뿐만 아니라 젓소의 산유량 및 유지방 향상에 도움이 된다고 보고 하여 (Belibasakis and Tsirgogianni, 1996; Chiou et al., 1998) 반추가축의 단백질 공급원으로 우수 함이 보고되어 왔다. 본 시험사료에 단백질 공 급원으로 $24.3 \sim 25 \%$ 배합된 맥주박과 비지는 대조구와 가소화 조단백질 섭취량 비교 시 뒤 떨어지지 않는 것으로 나타나 시판사료의 대체 가능성을 높이 시사하였다.

또한, 대사 체중 당 건물섭취량은 성장단계,
성별 등 여러 가지 요인에 의해 달리 나타나는 데, 농산부산물 급여 시 번식흑염소는 44.3 $50.3 \mathrm{~g}$ (Choi et al., 2006a), 육성기 거세흑염소 는 62.4 68.8 g (Choi et al., 2006b), 임신한 아프 리카 염소에게 타피오카와 맥주박을 급여 시에 는 45.7 61.7g (Osuagwuh and Akinsoyinu, 1990) 으로 다양한 섭취량을 보고하였다. 본 시험에 서 농산물 발효사료 급여구가 51.6 56 g으로 나 타나 비육단계의 흑염소의 섭취량을 충분히 충 족한 것으로 나타났으며, 특히 농산부산물을 $50 \%$ (맥주박 $15 \%$, 비지 $10 \%$, 버섯배지 $15 \%$, 미강 $10 \%$ 첨가한 $\mathrm{T} 1$ 구는 시판사료를 급여한 대조구와 대등한 섭취량을 나타내어 다양한 농 산부산물 배합과 발효는 기호성을 개선하여 높 은 섭취량을 나타낸 것으로 사료된다.

\section{3. 영양소 소화율}

농산부산물 첨가 발효사료를 흑염소에게 급 여하였을 때 영양소 소화율에 미치는 영향은 Table 5와 같다.

건물과 유기물 소화율은 대조구가 각각 67.60 과 $73.84 \%$ 로 농산부산물 첨가구보다 유의하게

Table 5. The effects of feeding experimental diets on the nutrient digestibility of Korean black goat (\%)

\begin{tabular}{lccccc}
\hline \multirow{2}{*}{ Items } & \multicolumn{4}{c}{ Treatments $^{1)}$} & \multirow{2}{*}{ SEM $^{2)}$} \\
\cline { 2 - 5 } & Control & $\mathrm{T} 1$ & $\mathrm{~T} 2$ & $\mathrm{~T} 3$ & \\
\hline \hline Dry matter & $67.60^{\mathrm{a}}$ & $61.99^{\mathrm{b}}$ & $62.94^{\mathrm{b}}$ & $53.95^{\mathrm{c}}$ & 1.67 \\
Organic matter & $73.84^{\mathrm{a}}$ & $69.04^{\mathrm{b}}$ & $69.46^{\mathrm{b}}$ & $61.58^{\mathrm{c}}$ & 1.60 \\
Crude protein & $70.45^{\mathrm{a}}$ & $69.43^{\mathrm{a}}$ & $67.63^{\mathrm{ab}}$ & $61.46^{\mathrm{b}}$ & 3.91 \\
$\mathrm{ADF}^{3)}$ & $46.03^{\mathrm{a}}$ & $43.01^{\mathrm{a}}$ & $38.99^{\mathrm{ab}}$ & $31.73^{\mathrm{b}}$ & 4.97 \\
$\mathrm{NDF}^{4)}$ & $67.44^{\mathrm{a}}$ & $55.86^{\mathrm{b}}$ & $54.98^{\mathrm{b}}$ & $40.35^{\mathrm{c}}$ & 3.46 \\
Ether extracts $^{5}$ & $78.06^{\mathrm{a}}$ & $69.03^{\mathrm{b}}$ & $69.82^{\mathrm{b}}$ & $67.66^{\mathrm{b}}$ & 2.14 \\
$\mathrm{NFC}^{5}$ & 80.80 & 81.39 & 84.07 & 82.14 & 3.17 \\
\hline
\end{tabular}

${ }^{1)}$ See Table 1, ${ }^{2)}$ Standard error of the mean, ${ }^{3)} \mathrm{ADF}=$ Acid detergent fiber,

${ }^{4)} \mathrm{NDF}=$ Neutral detergent fiber, ${ }^{5)} \mathrm{NFC}=$ Non-fibrous carbohydrate.

${ }^{a}, b, c$ Means in a row with different superscripts are significantly different $(p<0.05)$. 
높았고, 시험구간에는 미강을 $30 \%$ 첨가한 $\mathrm{T} 3$ 구가 각각 53.95 와 $61.58 \%$ 로 가장 낮았다 $(\mathrm{p}<$ $0.05)$. 조단백질 소화율은 $\mathrm{T} 1$ 과 $\mathrm{T} 2$ 구가 각각 69.43 과 $67.63 \%$ 로 대조구의 $70.45 \%$ 와 유의적 차이가 없었으며, 섬유소 소화율은 농산부산물 중 미강 첨가비율이 높을수록 유의하게 낮아져 미강 비율이 $30 \%$ 인 $\mathrm{T} 3$ 구가 가장 낮았다 $(\mathrm{p}<$ 0.05). 조지방 소화율에서도 대조구가 가장 높 았으나 ( $\mathrm{p}<0.05), \mathrm{NFC}$ 소화율은 80.80 84.07\%의 범위로 나타나 시험구간 차이가 없었다.

본 결과에서 농산부산물 발효사료 시험구의 건물소화율이 $53.95 \sim 61.99 \%$ 의 범위로 나타나, Jo 등 (1999)이 보고한 흑염소에게 미강 등의 농산부산물을 급여 시 건물 소화율이 43.1 $71.6 \%$ 이었으며, 맥주박 등의 농산부산물의 건 물 소화율은 번식흑염소는 57.3 60.1 (Choi et al., 2006a), 육성기 흑염소는 55.59 58.58\% 이 었다는 (Choi et al., 2006b) 결과와 유사하였다.

한편, 섭취 사료 중 전분 함량이 높을 때 반 추위 이용률이 높아져 생산성이 높아지며 (Mahgoub et al., 2000; Haddad, 2005), 반추위 에서 빨리 분해되는 탄수화물의 함량이 많을 때 반추위내 발효 효율이 향상되어 소화율이 높아진다(Beever et al., 1990)고 하였다. 본 시 험에서도 NFC 함량이 높고(Table 2), 섭취 및 가소화 NFC 섭취량이 높은 (Table 4) 시험구일 수록 발효효율이 향상되어 영양소 소화율도 높 게 나타난 것으로 사료된다.
또한, 반추가축에게 지방함량이 높은 사료 급여는 반추위내에서 가수분해된 long chain fatty acids가 섬유소 분해 박테리아의 활성을 저해하며 (Maczulak et al., 1981), 특히, 사료에 조지방 함량이 $5 \%$ 이상일 때 섬유소를 피복하 여 섬유소 소화율이 저하하여 (Palmquist and Jenkins, 1980), 반추위 발효여건에 악영향을 미 쳐 반추동물의 소화생리에 부정적이다(Elliott et al., 1997). 본 시험에서 지방의 함량이 높은 미강의 첨가 비율이 높을수록 소화율이 낮아진 것은 섬유소 분해 박테리아의 활성이 저하된 것으로 사료되며, 특히 사료의 조지방 함량이 $6.92 \%$ (Table 2)로 가장 높은 T3구는 조지방 함 량이 가장 낮은 $\mathrm{T} 1$ 구 $(3.16 \%)$ 의 $\mathrm{ADF}$ 및 $\mathrm{NDF}$ 소화율의 73.8 과 $72.2 \%$ 수준밖에 되지 않아 높 은 조지방 함량이 반추위 소화생리에 부정적인 영향을 미친 것으로 사료된다.

\section{4. 질소 축적}

농산부산물 첨가 발효사료를 흑염소에게 급 여하였을 때 질소축적에 미치는 영향은 Table 6 과 같다.

질소섭취량은 시판사료 급여구인 대조구가 $17.03 \mathrm{~g}$ 이었고 농산부산물 첨가구는 $16.06 \sim 17.56 \mathrm{~g}$ 으로 시험구간 유의적 차이는 나타나지 않았다. 질소 배설량은 농산부산물 첨가구가 10.41 $11.13 \mathrm{~g}$ 으로 대조구 $9.93 \mathrm{~g}$ 보다 높은 경향으로

Table 6. The effects of feeding experimental diets on nitrogen retention of Korean black goat

\begin{tabular}{lccccc}
\hline \multirow{2}{*}{ Items } & \multicolumn{4}{c}{ Treatments $^{1)}$} & \multirow{2}{*}{ SEM $^{2)}$} \\
\cline { 2 - 5 } & Control & $\mathrm{T} 1$ & $\mathrm{~T} 2$ & $\mathrm{~T} 3$ & \\
\hline \hline Total N Intake (g/day) & 17.03 & 17.56 & 17.13 & 16.06 & 1.36 \\
N Loss (g/day) & 9.93 & 10.41 & 11.13 & 11.13 & 0.80 \\
Nitrogen retention (g/day) & $7.10^{\mathrm{a}}$ & $7.15^{\mathrm{a}}$ & $6.00^{\mathrm{ab}}$ & $4.93^{\mathrm{b}}$ & 0.73 \\
Nitrogen retention (\%) & $41.69^{\mathrm{a}}$ & $40.72^{\mathrm{a}}$ & $35.00^{\mathrm{b}}$ & $30.69^{\mathrm{c}}$ & 2.38 \\
\hline
\end{tabular}

\footnotetext{
${ }^{1)}$ See Table $1,{ }^{2)}$ Standard error of the mean.

a, b, c Means in a row with different superscripts are significantly different $(p<0.05)$.
} 
나타났다. 한편, 질소축적량은 대조구와 $\mathrm{T} 1$ 구가 각각 7.1 과 $7.15 \mathrm{~g}$ 으로 $\mathrm{T} 3$ 구의 $4.93 \mathrm{~g}$ 보다 유의 하게 높았으며 $(\mathrm{p}<0.05)$, 질소축적률에서도 대조 구와 $\mathrm{T} 1$ 구가 각각 41.69 와 $40.72 \%$ 로 가장 높았 다 $(\mathrm{p}<0.05)$.

질소축적률은 사양방법, 먹이 및 성장단계에 따라 차이가 있으나, 본 시험결과 농산부산물 발효사료 시험구에서 질소축적률 30.69 40.72\% 는 Choi et al. (2006b)이 보고한 맥주박 첨가 사료를 거세흑염소에 급여하였을 때 32.2 $41.0 \%$ 결과와 거의 일치하는 경향이었다.

또한, 질소 섭취량은 건물 섭취량에 비례하 며 (Jia et al., 1995), 질소축적은 질소섭취량에 비례한다고 보고하여 (Atti, 2004) 본 시험 결과 에서도 질소섭취량이 낮은 $\mathrm{T} 3$ 구에서 질소축적 률이 낮게 나타난 것으로 사료된다.

이상의 결과를 종합하면 맥주박, 비지 및 버 섯 폐배지 등 농산부산물을 발효시켜 비육흑염 소의 사료로 급여하였을 때 $\mathrm{T} 1$ 과 $\mathrm{T} 2$ 구는 시판 사료를 급여한 대조구와 비교 시 증체는 86 $90 \%$, 건물소화율은 91.7 93.1\%의 수준을 보였 으며, 질소이용성은 대등한 수준을 보였다. 그 러나 미강의 첨가 비율이 높아질수록 사료효율 저하가 우려되므로 조지방 함량을 $5 \%$ 이하로 배합하는 것이 필요하다 판단된다.

\section{IV. 요 약}

본 연구는 농산부산물을 이용한 발효사료의 급여효과를 알아보기 위해 비육 흑염소의 생산 성 및 영양소 이용률을 조사하였다. 증체조사 를 위한 사양시험은 거세흑염소 24 두를 이용하 여 처리구당 6두씩 30일 수행하였고, 소화율 시험은 거세흑염소 12 두를 공시하여 처리구당 3 두씩 라틴방각법으로 실시하여, 처리구는 대 조구 (배합사료 및 볏짚 급여구)와 3 개의 시험 구(발효사료와 볏짚 급여구)로 각각 배치하였 다. 일당증체량은 대조구가 가장 높았고, T3구 가 가장 낮았다 $(\mathrm{p}<0.05)$. 1 일 두당 건물섭취량
과 유기물섭취량은 시판사료를 급여한 대조구 가 각각 718.8 과 $680.9 \mathrm{~g}$, 농산부산물 첨가구가 각각 634.2 699.2와 $602.8 \sim 660.4 \mathrm{~g}$ 으로 나타나 농산부산물 중 미강 첨가구가 높을수록 섭취량 이 낮아지는 경향으로 나타났다. 건물과 유기 물 소화율은 대조구가 농산부산물 첨가구보다 유의하게 높았고 $(\mathrm{p}<0.05)$. 시험구간에는 미강을 $30 \%$ 첨가한 $\mathrm{T} 3$ 구가 가장 낮았다 $(\mathrm{p}<0.05)$. 질소 축적률은 대조구와 $\mathrm{T} 1$ 구가 유의하게 높았다. 따라서, 본 연구의 결과 농산부산물을 이용한 발효사료 (T1과 $\mathrm{T} 2$ 구)는 시판사료를 급여한 대 조구와 비교 시 증체는 86 90\%, 건물소화율은 91.7 93.1\%의 수준을 보였으며, 질소이용성은 대등한 수준을 보였다. 그러나 미강의 첨가 비 율이 높아질수록 사료효율 저하가 우려되므로 조지방 함량을 $5.0 \%$ 이하로 배합하는 것이 필 요하다 판단된다.

\section{V. 인 용 문 헌}

1. A.O.A.C. 1995. Official Methods of Analysis. 16th ed. Association of Official Analytical Chemists. Washington, DC.

2. Atti, N., H. Rouissi and M. Mahouachi. 2004. The effect of dietary crude protein level on growth, carcass and meat composition of male goat kids in Tunisia. Small Rumin. Res. 54:89-97.

3. Beever, D.E., M. Gill, J.M. Dawson and P.J. Butery. 1990. The effect of fish meal on the digestion of grass silage by growing cattle. Brit. J. Nutr. 63:498-502.

4. Belibasakis, N.G. and D. Tsirgogianni. 1996. Effects of wet brewers grains on milk yield, milk composition and blood components of dairy cows in hot weather. animal Feed Science and Technology 57:175-181.

5. Chiou, P.W.S., C.R. Chen, K.J. Chen and B. Yu. 1998. Wet brewers' grains or bean curd pomance as partial replacement of soybean meal for lactating cows. Animal Feed Science and Technology 74:123-134.

6. Choi, S.H., S. Hwangbo, S.W. Kim, B.D. Sang, 
Y.K. Kim and I.H. Jo. 2006a. Effects of total mixed ration with wet brewer's grain on nutrient utilization in breeding Korean native goats. J. Kor. Grassl. Forage Sci. 26(3):147-154.

7. Choi, S.H., S. Hwangbo, S.W. Kim, B.D. Sang, Y.K. Kim and I.H. Jo. 2006b. Effects of total mixed ration with wet brewer's grain on the performance and nutrient utilization in castrated Korean black goats. J. Kor. Grassl. Forage Sci. 26(4):199-206.

8. Elliott, J.P., J.K. Drackley, C.G. Aldrich and N.R. Merchen. 1997. Effects of saturation and esterification of fat sources on site and extent of digestion in steers: Ruminal fermentation and digestion of organic matter, fiber, and nitrogen. J. Anim. Sci. 75:2803.

9. Gondwe, T.N.P., J.P. Mtimuni and A.C.L. Safalaoh. 1999. Evaluation of brewery by-products replacing vitamin premix in broiler finisher diets. Indian Journal of Animal Sci. 69:347-349.

10. Haddad, S.G. 2005. Effect of dietary forage: concentrate ratio on growth performance and carcass characteristics of growing Baladi kids. Small Rumin. Res. 57:43-49.

11. Hathch, C.F., T.W. Perry, M.T. Mohler and W.M. Beeson. 1972. Effect of corn distillers solubles and brewers dried grains with yeast in ureacontaining rations on steer with yeast in ureacontaining rations on steer performance. J. Anim. Sci. 34:326.

12. Jia, Z.H., T. Sahlu, J.M. Fernandez, S.P. Hart and T.H. Teh. 1995. Effects of dietary protein level on performance of Angora and cashmere-producing Spanish goats. Small Rumin. Res. 16:113-119.

13. Jo, I.H., S. Hwangbo, J.H. Ahn and J.S. Lee. 1999. Use of apple pomace and rice bran of agricultural by products for the development of diets of Korean native growing goats. Kor. J. Anim. Nutr. Feed. 23(4):327-334.

14. Kim, Y.I., S.H. Jung, S.Y. Yang, J.W. Huh and W.S. Kwak. 2007. Ruminant Nutrition : Effects of cellulolytic microbes inoculation during deep stacking of spent mushroom substrates on cellulolytic enzyme activity and nutrients utilization by sheep. J. Anim. Sci. \& Technol. (Kor.) 49(5):667-676.

15. Lee, D.Y., J.L. Go, N.J. Choe, S.S. Lee, J.Y.
Song, S.Y. Lee, S.H. Park, H.G. Seong and J.G. Ha. 2003. Ruminant nutrition : Effects of types of TMR on rumen fermentation characteristics and nutrients digestibility in sheep. J. Anim. Sci. \& Technol. (Kor.) 45(5):805-812.

16. Lee, S.M. 2008. Effects of agricultural by-product feeds on growth and carcass characteristics of Korean native steer. J. Kor. Grassl. Forage Sci. 28(1):41-48.

17. Macleod, A.M. 1979. The physiology of malting, In: Pollock, J. R. A.(Ed). Brewing Science, vol. 1. Academic Press, New York, pp. 145-232.

18. Maczulak, A.E., B.A. Dehority and D.L. Palmquist. 1981. Effect of long-chain fatty acids on growth of rumen bacteria. Appl. and Envi. Microbio. 42(5):856-862.

19. Mahgoub, O., C.D. Lu and R.J. Early. 2000. Effects of dietary energy density on feed intake body weight gain and carcass chemical composition of Omani growing lambs. Small Rumin. Res. 37:35-42.

20. McCarthy, F.D., S.A. Norton and W.H. McClure. 1990. Utilization of an ensiled wet brewers' grains-corn mixture by growing lambs. Animal Feed Science and Technology. 28:29-38.

21. NRC. 1981. Nutrient requirements of goats, National academy of sciences - National reserch council, Washington D. C.

22. Osuagwuh, A.I.A. and A.O. Akinsoyinu. 1990. Efficiency of nitrogen utilization by pregnant West African dwarf goats fed various levels of crude protein in the diet. Small Rumin. Res. 3:363-371.

23. Palmquist, D.L. and T.C. Jenkins. 1980. Fat in lactation ration. Rev. J. Dairy Sci., 63:1-14.

24. Polan, C.E. and T.A. Herrington, W.A. Wark and L.E. Armentano. 1985. Milk production response to diets supplemented with dried brewers grains, wet brewers grains, or soyahean meal. J. Dairy Sci. 68:2016-2026.

25. RDA National Institute of Animal Science. 2007. The use of valuable microorganisms in livestock industry. Sammi Press. Suwon. pp. 42-48.

26. SAS. 2000 SAS/STAT ${ }^{\circledR}$ User's guide (Release 8.1 ed.). Statistics, SAS Inst, Inc., Cary, NC.

27. Steel, R.G.D. and J.H. Torrie. 1980. Principles and procedures of statistics: A biometrical approach 
(2nd Ed.). McGraw-Hill Bok Co., New York.

28. Van Soest, P.J., J.B. Robertson and B.A. Lewis. 1991. Methods for dietary fiber, neutral detergent fiber, and non-starch polysaccharides in elation to animal nutrition. J. Dairy Sci. 74:3583-3597.
29. West, J.W., L.O. Ely and S.A. Martin. 1994. Wet brewers grains for lactating dairy cows during hot. humid weather. J. Dairy Sci. 77:1496.

(Received January 4, 2012/Accepted February 29, 2012) 